\title{
PERANAN PERUSAHAAN MEBEL KAYU TERHADAP PEMBANGUNAN EKONOMI KABUPATEN GORONTALO
}

\author{
Usman Musa Sjahrain \\ Institut Agama Islam Negeri Manado \\ Email: usmansjahrain69@gmail.com
}

\begin{abstract}
Economic development is defined as a series of efforts in an economy to develop its economic activities so that more infrastructure is available and more companies are developing, higher levels of education and technology are increasing. As an implication of this development, it is expected that employment opportunities will increase, income levels increase, and the prosperity of the community will increase. Luwoo village community, is not as expected as a village with more economic growth, but in reality there are still many people with low unemployment and income levels. Efforts to build rural communities are by developing rural small-scale business activities so that urbanization can cope with the flow of urbanization because rural communities want to find employment and a source of income. The results showed that the wood furniture company in the village of Luwoo was carried out to work on various kinds of production, using permanent and non-permanent workers. The average income is around Rp. 10,000, up to Rp. 30,000 per day. A contingency significance test and a multiple correlation test are carried out stating that wood furniture companies that use capital, technology and raw materials together (simultaneously) play a very significant role in economic development, especially income.
\end{abstract}

Keywords: Company Role; Wooden Furniture; Economic Development 


\section{PENDAHULUAN}

Negara Indonesia adalah negara berdasarkan hukum (rechstats) bukan Negara berdasarkan atas kekuatan atau kesewenang-wenangan. Oleh karena itu, segala sesuatu yang berhubungan dengan kenegaraan dari segi ekonomi, politik, sosial, budaya akan diatur oleh hukum. Sebagaimana telah tertulis dalam tujuan negara di dalam pembukaan UUD 1945 bahwa negara bertujuan untuk melindungi segenap bangsa Indonesia, memajukan kesejahteraan umum, mencerdaskan kehidupan bangsa dan ikut melaksanakan ketertiban dunia (Undang - Undang Dasar 1945, Pembukaan, alinea ke empat).

Dalam hal memajukan kesejahteraan umum (rakyat)tentunya negara mempunyai regulasi agar tujuan tersebut dapat tercapai secara baik.Dalam kehidupan sehari-hari manusia tidak bisa terlepas dari kegiatan ekonomi.Kegiatan ekonomi inimerupakan kegiatan yang melibatkan lebih dari satu individu atau satu organ. Oleh karena itu, pembentuk berjalannya kegiatan ekonomi adalah organ (individu dan atau korporasi dalam jumlah lebih dari satu) yang saling membutuhkan dan saling melengkapi dalam proses kegiatan ekonomi. Para pelaku ekonomi saling berinteraksi hingga terjadinya transaksi ekonomi.

Pelaku Ekonomi di Indonesia pada hakekatnya sangat bervariasi, baik mengenai eksistensinya di dalam peraturan kegiatannya maupun kedudukan institusinya. Pada strata terendah biasanya terdiri dari pelaku ekonomi perorangan dengan kekuatan modal yang relatif terbatas. Pada strata menengah ke atas dapat dijumpai beberapa bentuk badan usaha, baik yang bukan Badan Hukum maupun yang mempunyai status sebagai Badan Hukum yaitu Perseroan Terbatas dan Koperasi sebagai suatu Korporasi, Perseroan Terbatas atau PT, pasti mempunyai kemampuan untuk lebih mengembangkan dirinya dibandingkan dengan Badan Usaha yang lain, terutama yang tidak berbentuk Badan Hukum dalam menjalankan perannya sebagai pelaku ekonomi (Hartono, Sri Rejeki, 2013).

Eksistensi perusahaan sebagai salah satu pelaku ekonomi di Indonesia tidak dapat dielakkan lagi. Perusahaan sudah menjadi salah satu anggota komunitas masyarakat. Bahkan hadirnya perusahaan dimasyarakat telah membuat tatanan baru dalam komunitas akar rumput (masyarakat bawah). Tatanan tersebut dapat berupa tatanan ekonomi maupun tatanan sosiologis. Hadirnya perusahaan di tengah-tengah masyarakat ini tentunya memainkan peran dalam sistem ekonomi di Indonesia.

Ekonomi adalah sebagai berikut.Sebagai produsen, dengan menghasilkan barang dan jasa yang dibutuhkan oleh rumah tangga keluarga, pemerintah, bahkan masyarakat luar negeri.Oleh sebab itu, setiap perusahaan wajib memerhatikan kualitas dan kuantitas produksinya sesuai dengan kebutuhan konsumen.Sebagai distributor, sebagai mata rantai penyaluran barang dalam rangka melayani konsumen agar barang yang dibutuhkan sampai pada konsumen tepat waktu, tepat tempat, tepat sasaran, tepat kuantitas, dan tepat kualitas sehingga barang yang dibutuhkan masyarakatdengan gampang dapat diperoleh. Sebagai agen pembangunan, kegiatan perusahaan sebagai agen pembangunan ditujukan untuk meningkatkan produksi melalui penelitian dan 
pengembangan. Setiap perusahaan selalu berusaha supaya tidak ketinggalan ilmu dan teknologi serta dapat mengembangkan diri sesuai dengan kemajuan zaman. Perusahaan yang mencapai sukses dapat dikatakan berfungsi sebagai agen pembangunan. Perusahaan yang demikian tidak hanya mengejar keuntungan untuk pemilik modal, tetapi bertanggung jawab pula atas kesejahteraan karyawan khususnya dan masyarakat umumnya.

Semakin berkembangnya zaman, kita dituntut untuk bisa menghasilkan suatu karya untuk memenuhi kebutuhan hidup. Salah satunya yaitu dengan memproduksi suatu barang. Produksi adalah suatu kegiatan yang dikerjakan untuk menambah nilai guna suatu benda baru sehingga lebih bermanfaat dalam memenuhi kebutuhan manusia dengan menghasilkan barang dan jasa.

Salah satu contoh produksi barang dan jasa adalah meubel. Perusahaan meubel merupakan salah satu sektor perusahaan yang terus berkembang. Meubel digunakan banyak orang karena kegunaanya yang banyak dalam kehidupan kita. Bentuk meubel antara lain kusen pintu, kursi, meja, almari, dan ranjang yang terbuat dari kayu dan peralatan rumah tangga lainnya. Pada umumnya, sebuah rancangan meubel lahir karena adanya kebutuhan terhadap fungsi meubel tersebut.

Ekonomi merupakan perkataan yang berasal dari bahasa yunani kuno (greek) yaitu "oicos" yang berarti rumah dan "nomos" yang berarti aturan. Maksudnya adalah aturan-aturan untuk menyelenggarakan kebutuhan hidup dalam rumah tangga, baik setingkat rumah tangga rakyat atau setingkat rumah tangga negara. Itu adalah ekonomi secara umum sedangkan ekonomi secara dalam islam sering disebut dengan nama almu'amalah yang berarti aturan-aturan tentang pergaulan dan perhubungan manusia mengenai kebutuhan hidupnya.

Mengingat konsep Ilmu Ekonomi sebagai tolak ukur kajian pertumbuhan ekonomi yang sudah terlanjur diyakini serta diterapkan secara luas, maka kita tidak boleh ketinggalandan mau tidak mau juga harus berusaha mempelajari hakekat dan konsep - konsep Ilmu Ekonomi tersebut. Kajian-kajian Ilmu Ekonomi semakin gencar didedikasikan untuk pengetahuan bagi masyarakat umum dengan tujuan masyarakat mengetahui tujuan ekonomi itu sendiri. Dengan demikian makin tingginya pengetahuan masyarakat tentang tujuan ekonomi diharapkan juga dengan meningkatnya kesejahteraan masyarakat. Dalam kajiannya Ilmu ekonomi memiliki metode-metode yang digunakan dalam mengatasi permasalahan yang timbul dalam masyarakat sehingga akan didapatkan manfaat dan kaidah ekonomi dalam masyarakat. Dari Ilmu Ekonomi diharapkan dapat mempertinggi efisiensi faktor-faktor produksi dalam masyarakat serta menentukan sebab dan cara mengatasi masalah dalam ekonomi sebagi salah satu kegiatan yang harus dilaksanakan.

Pembangunan ekonomi diartikan sebagai serangkaian usaha dalam suatu perekonomian untuk mengembangkan kegiatan ekonominya sehingga infrastruktur lebih banyak tersedia, perusahaan semakin banyak dan semakin berkembang, taraf pendidikan semakin tinggi dan teknologi semakin meningkat (Sadono Sukirno, 2006). Sebagai implikasi dari perkembangan ini diharapkan kesempatan kerja semakin 
bertambah, tingkat pendapatan meningkat, dan kemakmuran masyarakat manjadi semakain baik. Pertumbuhan dan pembangunan ekonomi. Dalam analisis ekonomi perlu dibedakan arti pertumbuhan ekonomi dan pembangunan ekonomi. Kedua konsep ini in tinggimempunyai pengertian yang sedikit berbeda. Istilah pertumbuhan ekonomi menerangkan atau mengukur prestasi dari perkembangan sesuatu ekonomi. Dan istilah pembangunan ekonomi biasanya dikaitkan dengan perkembangan ekonomi di negaranegara berkembang, Sebagian ahli ekonomi mengartikan istilah ini sebagai berikut: economic development is growth plus change yaitu pembangunan ekonomi adalah pertumbuhan ekonomi yang diikuti oleh perubahan dalam struktur dan corak kegiatan ekonomi (Sadono Sukirno, 2006).

Masalah ekonomi sering timbul dikarenakan adanya ketidak seimbangan antara keinginan pemenuhan kebutuhan dengan kemampuan factor-faktor produksi yang bisa memenuhi keinginan tersebut. Hak ini menyebabkan perlunya pembuatan pilihan-pilihan sehingga agar kesejahteraan dalam menggunakan faktor-faktor produksi yang tersedia dapat terpenuhi.

Kegiatan ekonomi meliputi berbagai jenis kegiatan produksi, konsumsi, dan perdagangan. Ada 3 persoalan pokok dalam perekonomian: (Mashudi, Djohan, 2017: 3)

1. Apakah barang dan jasa yang harus diproduksi dan berapa banyaknya?

Persoalan ini adalah persoalan yang sangat penting karena ia merupakan factor yang utama yang akan menentukan penggunaan faktor-faktor produksi Barang dan dihasilkan dalam suatu perekonomian adalah sangat banyak jenisnya.

2. Bagaimanakah barang- barang diproduksikan?

Biasanya terdapat beberapa cara untuk menghasilkan suatu barang. Adanya beberapa kemungkinan untuk menghasilkan suatu barang dapat dengan jelas dilihat. Masalah efesiensi merupakan salah satu factor yang akan dijadikan dasar dalam melakukan pemilihan tersebut. Yang dipilih adalah yang mampu untuk menciptakan barang - barang tersebut dengan cara yang paling efesien.

3. Untuk siapakah barang-barang diproduksikan?

Masalah selanjutnya yang harus dipikirkan masyarakat adalah bagaimanakah pendapatan keseluruhan masyarakat didistribusikan kepada berbagai golongan dan individu dalam masyarakat itu? Untuk menjawab persoalan ini, yang pertama - tama harus dibuat adalah menentukan cara-cara pendapatan dari factor-faktor produksi ditentukan, yaitu bagaimana caranya upah tenaga kerja, sewa tanah, bunga modal dan keuntungan para pengusaha ditentukan.

Dalam memenuhi kebutuhannya, manusia dihadapkan pada berbagai masalah. Hal ini dimungkinkan karena jumlah dan macam kebutuhan manusia tidak terbatas. Masalah pokok ekonomi yang dihadapi manusia dibedakan menjadi dua macam, yaitu masalah bagi produsen dan konsumen. Masalah ekonomi yang dihadapi konsumen 
Masalah pokok yang dihadapi konsumen adalah terbatasya alat pemuas, padahal kebutuhan manusia tidak terbatas. Agar konsumen dapat memenuhi berbagai kebutuhannya maka konsumen akan menyusun skala prioritas. Adapun hal-hal yang mempengaruhi skala prioritas adalah tingkat pendapatan atau penghasilan, kedudukan seseorang, dan faktor lingkungan.

Selama ini banyak negara sedang berkembang telah berhasil menunjukkan laju pertumbuhan ekonomi yang cukup tinggi, tetapi masih banyak permasalahan pembangunan yang belum terpecahkan, seperti : tingkat pengangguran tetap tinggi, pembagian pendapatan tambah tidak merata, masih banyak terdapat kemiskinan absolut, tingkat pendidikan rata-rata masih rendah, pelayanan kesehatan masih kurang, dan sekelompok kecil penduduk yang sangat kaya cenderung semakin kaya sedangkan sebagian besar penduduk tetap saja bergelut dengan kemiskinan, yang terjadi bukan trickle down tapi trickle up, dapat mengkaji permasalahan yang ada agar tidak menjadi sebuah ketimpangan ekonomi.

Salah satu kegiatan perusahaan yang sudah lama dikembangkan oleh perusahaan mebel kayu desa Luwoo Kecamatan Telaga Jaya Kabupaten Gorontalo dan kegiatan produksinya seperti pembuatan kursi, keranjang bunga dan buah, kerans bunga, vas bunga, cenderamata, parcel, hiasan dinding, rak sepatu dan lain-lain. Kegiatan tersebut memerlukan keahlian khusus dalam menciptakan model dan desain yang sesuai dengan pesanan produk.

Dalam mengembangkan model dan desain produk dibutuhkan tenaga kerja yang memiliki keterampilan, pengetahuan dan pengalaman kerja dengan sendirinya akan meningkatkan pula kemampuan kerjanya, baik dalam kecepatan kerja maupun dalam mutu hasilnya, sehingga dapat memenuhi permintaan hasil produknya. Dengan demikian pendapatan yang mereka peroleh dari hasil pekerjaannya akan memenuhi taraf hidup yang sejahtera dan memberikan daya beli yang cukup tinggi kepada masyarakat dan seterusnya menimbulkan permintaan efektif mengenai barang dan jasa yang dihasilkan dalam pembangunan. Pengamatan tingkat kehidupan sosial dan ekonomi masyarakat Desa Luwoo belum seperti yang diharapkan sebagai desa dengan pertumbuhan ekonomi masyarakat yang lebih meningkat, pada hal keadaan masyarakat desa Luwoo umumnya sebagai pengusaha dan karyawan atau buruh pekerja pengusaha dengan mengharapkan tingkat kesejahteraan sosial dan pendapatan yang lebih tinggi, tetapi pada kenyataannya masih banyak masyarakat dengan tingkat pengangguran dan pendapatannya rendah. Dari masalah ini penulis ingin meneliti dengan judul "Peranan Perusahaan Mebel Kayu Terhadap Pembangunan Ekonomi Kabupaten Gorontalo"

\section{METODOLOGI PENELITIAN}

Metodologi Penelitianyang digunakan pada penelitian ini bermanfaat sebagai berikut : 1). Mengetahui arti pentingnya penelitian, sehingga keputusan-keputusan yang dibuat dalam hidup sehari - hari mungkin berdasarkan atas hasil penelitian, baik didalam memecahkan persoalan ataupun mencari hal-hal baru, 2). Menilai hasil penelitian, apakah suatu penelitian dapat dipertanggungjawabkan dan sampai seberapa juah 
kebenaranya, 3). Dapat menyusun karya ilmiah dengan baik karena penyusunan memerlukan cara-cara tertentu yang ilmiah (Sukirno, 1994). dan kritik.

Metodologi penelitian melatih berpikir ilmiah, yaitu bersikap skeptis, analitik

Beberapa metode yang digunakan dalam ilmu ekonomi sebagai berikut:

\section{Metode Statistika}

Cara pemecahan masalah ekonomi dengan metode ini yaitu dengan cara pengumpulan data pengolahan, analisis, penafsiran, dan penyajian data dalam bentuk angka-angka secara statistik. Melalui data tersebut, maka akan diketahui permasalahannya lalu dicari cara pemecahannya yang tepat.

\section{Metode Induktif}

Metode ini dilakukan dengan cara mengumpulkan semua data informasi yang dialami individu, keluarga, maupun masyarakat lokal yang mencari jalan pemecahan sehingga upaya pemenuhan kebutuhan tersebut dapat dikaji secermat mungkin.

\section{Metode Deduktif}

Bila menggunakan metode ini, maka diperlukan hukum, ketentuan, atau prinsip umum yang sudah diuji kebenarannya. Dengan metode ini, ilmu ekonomi menetapkan cara pemecahan masalah sesuai dengan acuan, prinsip, hukum, dan ketentuan yang ada dalam ilmu ekonomi.

\section{Metode Matematika}

Metode ini digunakan untuk memecahkan masalah ekonomi dengan cara pemecahan soal-soal secara matematis. Dengan pembahasan dalil-dalil matematika dapat dipastikan bahwa kajiannya dapat diterima secara umum.

\section{HASIL PENELITIAN DAN PEMBAHASAN}

\section{Hasil Analisis Perusahaan Mebel kayu Terhadap Pembangunan Ekonomi}

Sesuai pengamatan dilapangan dan survei awal diduga perusahaan mebel kayu(X)terdiri dari faktor Modal (X1), Teknologi (X2) dan Bahan Baku (X3) secara bersama - sama (simultan) mempunyai hubungan terhadapPembangunan Ekonomi(Y) di khususnya pendapatan (Y1)di Kabupaten Gorontalo. (Hipotesis 1.)

Tabel.15. Menunjukkan hasil analisis kontingensiganda dengan uji keberartian kontingensi ganda yang menyatakan bahwa faktor-faktor modal (X1), teknologi (X2) dan bahan baku (X3) yang digunakan perusahaan mebel kayu (X) secara bersama-sama (simultan) merupakan suatu kesatuan yang dapat digunakan sebagai penduga yang mempunyai hubungan sangat signifikan terhadap Pembangunan Ekonomi (Y) khusus 
pendapatan (Y1). Kesesuaian model ini dibuktikan dengan nilai statistik $\chi^{2} 1_{\text {hit }}=31,86>$ $\chi_{\text {daf }}^{2}=26,3$ (tabel 15). Dengan demikian kedua nilai hipotesis H1 diterima pada taraf nyata $\alpha=0,05$ atau 5\% memberikan pengujian yang sangat signifikan atau sangat berarti.

Hasil analisis korelasi ganda dengan koefisien determinasi $\mathrm{R} 1^{2}=0,5194$ atau 51,94 persen (tabel 15). Ini berarti bahwa 51,94 persen dari variasi pendapatan (Y1) dapat dijelaskan oleh faktor-faktor modal (X1), teknologi dan bahan baku (X3) secara bersama-sama (simultan) yang digunakan perusahaan mebel kayu (X). Dengan demikian perusahaan mebel kayu yang menggunakan modal, teknologi dan bahan baku secara bersama-sama (simultan) berpengaruh pembangunan ekonomi khususnya pendapatan sebesar 51,94 persen.

Tabel 15. Hasil Analisis Perusahaan Mebel Kayu(X)

Terhadap Pembangunan Ekonomi (Y)

\begin{tabular}{|c|c|c|c|c|c|}
\hline \multirow{2}{*}{ No. } & \multirow{2}{*}{$\begin{array}{c}\text { Analisis } \\
\text { Variabel X dan Y }\end{array}$} & \multicolumn{3}{|c|}{ Koefisien } & \multirow{2}{*}{$\chi^{2} i$ hit } \\
\hline & & $\mathrm{C} i$ & $\mathrm{R} i$ & $\mathrm{R} i^{2}$ & \\
\hline \multirow[t]{5}{*}{$\overline{I .}$} & Kontig.dan Korelasi Ganda & & & & \\
\hline & Pendapatan (Y1) & & & & \\
\hline & Modal (X1) & & & & \\
\hline & Teknologi (X2) & 0,7178 & 0,7207 & 0,5194 & $31,86^{*}$ \\
\hline & Bahan Baku (X3) & & & & \\
\hline \multirow[t]{5}{*}{ II. } & Konting.dan Korelasi Parsial & & & & \\
\hline & Pendapatan (Y1) & & & & \\
\hline & Modal (X1) & 0,5711 & 0,5114 & 0,2615 & $14,52 *$ \\
\hline & Teknologi (X2) & 0,4377 & 0,4777 & 0,2282 & 7,11 \\
\hline & Bahan Baku (X3) & 0,5043 & 0,4384 & 0,1922 & $10,23 *$ \\
\hline
\end{tabular}

Catatan :

$\chi_{\text {daf }}^{2}=0,95(16)=26,3$

$\chi_{\text {daf }}^{2}=0,95(4)=9,49$

* = Hubungan Sangat Signifikan

Untuk mengetahui tingkat keberartian perusahaan mebel kayu(X)masingmasing faktor yang diduga modal (X1), teknologi (X2) dan bahan baku (X3) secara terpisah-pisah yang dapat digunakan sebagai penduga yang mempunyai hubungan 
Tasharruf: Journal Economics and Business of Islam Vol. 4, No. 2 (2019):110-127

Website: http://journal.iain-manado.ac.id/index.php/TJEBI

ISSN 2528-0325 (online) ISSN 2528-0317 (print)

berpengaruh terhadap Pembangunan Ekonomi (Y) khusus pendapatan (Y1) diKabupaten Gorontalo. (Hipotesis 2.)

Untuk lebih jelas maka dibawah ini diuraikan keberartian pengaruhmasingmasing faktor yang digunakan perusahaan mebel kayu sebagai berikut :

\section{Modal}

Kemampuan modal bagi pengusaha yang digunakan perusahaan mebel kayu berpengaruh terhadap pembangunan ekonomi khusus pendapatan. Tabel 15, menunjukkan hasil analisis kontingensi parsial dengan uji keberartian kontingensi parsial menyatakan bahwa faktor modal (X1) yang digunakan perusahaan mebel kayu (X) mempunyai hubungan sangat signifikan terhadap pembangunan ekonomi (Y) khusus pendapatan (Y1). Model ini dibuktikan dengan nilai statistik $\chi^{2} 21_{\text {hit }}=14,52>$ $\chi_{\text {daf }}^{2}=9,49$ hipotesis $\mathrm{H} 1$ diterima pada taraf nyata $\alpha=0,05$ atau 5\% memberikan pengujian yang sangat signifikan atau sangat berarti. Analisis kontingensi parsial ini, dapat dilihat pada tabel 16 sebagai berikut :

Tabel 16. Kontingensi Parsial

Antara (Y1) dan (X1)

\begin{tabular}{|c|cc|cc|cc|c|}
\hline \multirow{2}{*}{$\begin{array}{c}\text { Analisis } \\
\text { Variabel XI dan Y }\end{array}$} & \multicolumn{5}{|c|}{ Pendapatan (Y1) } & \multirow{2}{*}{ Jumlah } \\
\cline { 2 - 7 } & Tinggi & \multicolumn{2}{|c|}{ Sedang } & Rendah & \\
\hline \hline Modal (X1) & & & & & & \\
Mudah & 0 & 0 & 0 & 0 & 4 & $11^{*}$ & 11 \\
Agak Sulit & 4 & $11^{*}$ & 2 & $4^{*}$ & 0 & 0 & 15 \\
Sulit & 0 & 0 & 1 & 4 & 0 & 0 & 4 \\
\hline Jumlah & & $\mathbf{1 1}$ & & $\mathbf{8}$ & & $\mathbf{1 1}$ & $\mathbf{3 0}$ \\
\hline
\end{tabular}

Tabel 18. Menunjukkan kontingensi parsial dari 30 responden yang diteliti, sebanyak 11 dan 4 responden masing-masing menyatakan kemampuan modal yang digunakan perusahaan mebel kayu termasuk kategori agak sulit dan pembangunan ekonomi khususnya pendapatan termasuk tingkat kategori tinggi dan sedang, serta 11 responden menyatakan kemampuan modal yang digunakan perusahaan mebel kayu termasuk kategori mudah tetapi pembangunan ekonomi khususnya pendapatan termasuk kategori rendah.

Tabel 16. Menunjukkan hasil analisis korelasi parsial dengan koefisien determinasi $\mathrm{r}^{2} \mathrm{y} 1.23=0,2615$ atau 26,15 persen dari variasi pembangunan ekonomi (Y) khusus pendapatan (Y1) dapat dijelaskan oleh faktor modal (X1) yang digunakan perusahaan mebel kayu (X), dalam penelitian ini yang dimaksud dengan modal adalah modal berupa uang atau dana dan peralatan yang digunakan i perusahaan mebel kayu 
yang dilihat adalah jumlah dana yang dikeluarkan rata-rata sebesar Rp. 35 juta per bulan, memiliki peralatan yang lebih lengkap dan perolehan dana dari usaha sendiri maupun pinjaman dari lembaga keuangan seperti KUD atau bank desa yang ada di desa Luwoo.

Ketersediaan lembaga-lembaga perkreditan yang diarahkan untuk daerah-daerah pedesaan di rasakan masih menyulitkan para nasabahnya, tidak mengarah pada kemanfaatan dan kebutuhan produksi yang nyata, tetapi lebih mengutamakan sistem perbankannya.Dalam perkembangan perusahaan kecil dipedesaan sangat diperlukan adanya lembaga - lembaga perkreditan yang dapat menyandang dana untuk kebutuhankebutuhan produksi yang nyata dan mampu menyesuaikan diri dengan tingkat kemajuan masyarakat desa.Selain dari itu, lembaga-lembaga tersebut diharapkan pula membantu dalam menghadapi masalah pemasaran hasil produksi perusahaan kecil.

Umumnya pengusaha kecil dan menengah pada tahap-tahap awal perkembangan usahanya menggunakan modal sendiri, pinjaman dari keluarga atau temanteman untuk biaya operasional. Hal ini disebabkan karena lembaga-lembaga keuangan yang bertanggung jawab untuk langkah-langkah ini sangat terkonsentrasi pada wilayahwilayah tertentu dengan pusat-pusat pembangunan, misalnya diwilayah Ibu kota Propinsi. Akibatnya pengusaha kecil dan menengah yang ada diwilayah pedesaan akan mengalami masalah untuk mengembangkan usahanya (Clapman, R., 1991).

Tabel lampiran 7. Diperoleh data lapangan menunjukkan bahwa 63,33 persen responden berada pada kategori agak sulit dan sulit, industri memiliki modal, berupa peralatan yang lengkap dari usaha sendiri dan dana yang cukup dikeluarkan setiap bulan rata-rata Rp.35 juta dari usaha sendiri karena belum tersedianya lembaga-lembaga keuangan seperti Koperasi Unit Desa, Bank Desa dan lain-lain yang dapat menyandang dana untuk kebutuhan produksi pada perusahaan mebel kayu.

Faktor modal sangat penting, merupakan kunci. Dalam hal ini modal dimaksud adalah yang dimiliki oleh rakyat pedesaan, misalnya melalui koperasi. Karena perusahaan milik rakyat pedesaan akan dengan sendirinya meningkatkan pendapatan disektor pedesaan. Faktor pembentukan modal erat hubungannya dengan penampungan pengangguran (Rahardjo, 1986).

Dalam masalah perusahaan mebel kayu di desa Luwoo, belum ada institusi yang mengatur kelembagaannya sehingga sulit untuk bergerak lebih luwes dalam pengadaan modal. Akibatnya pendapatan, belum berperan secara nyata atau signifikan oleh kemampuan penggunaan modal para pengusaha kecil.

\section{Teknologi}

Pemanfaatan teknologi adalah perubahan fungsi produk pada perusahaan mebel kayu dapat disesuaikan dengan kebutuhan produksi. Teknologi yang digunakan perusahaan mebel kayu berpengaruh terhadap pembangunan ekonomi khusus pendapatan. Tabel 15, menunjukkan hasil analisis kontingensi parsial dengan uji keberartian kontingensi parsial menyatakan bahwa faktor teknologi (X2) yang digunakan perusahaan mebel kayu (X) mempunyai hubungantidaksignifikan terhadap

118 | Peranan Perusahaan Mebel Kayu terhadap Pembangunan Ekonomi Kabupaten Gorontalo Usman Musa Sjahrain 
pembangunan ekonomi (Y) khusus pendapatan (Y1).Model ini dibuktikan $\chi^{2} 22_{\text {hit }}=$ $7,11<\chi^{2}$ daf $=9,49$ hipotesis H1 ditolak pada taraf nyata $\alpha=0,05$ atau $5 \%$ memberikan pengujian yang tidak signifikan atau tidak berarti. Analisis kontingensi parsial ini, dapat dilihat pada tabel 17 , sebagai berikut :

Tabel 17. Kontingensi Parsial

Antara (Y1) dan (X2)

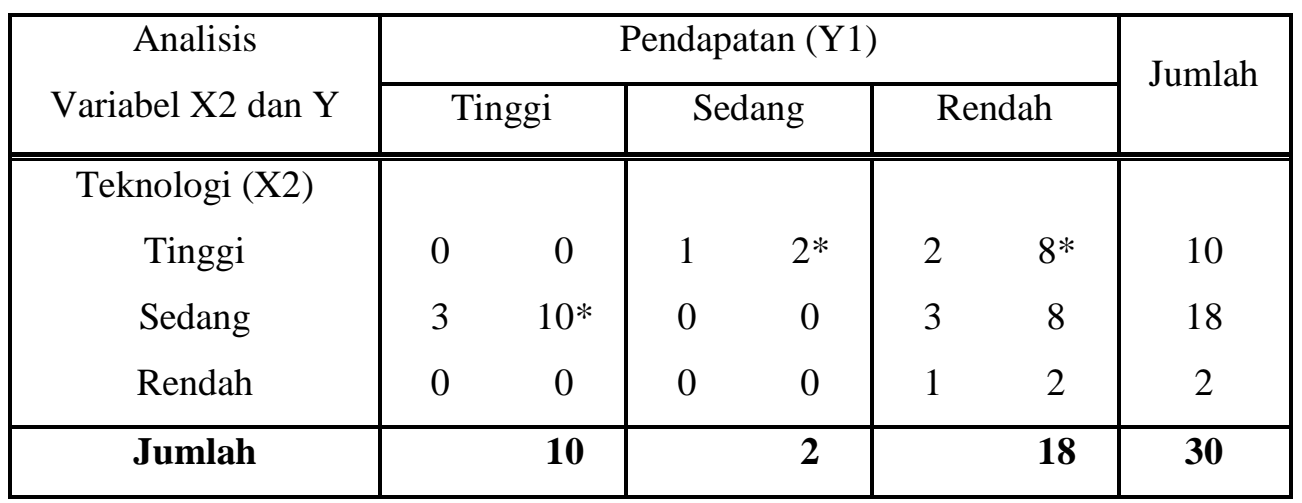

Tabel 17. Menunjukkan kontingensi parsial dari 30 responden yang diteliti, sebanyak 10 responden menyatakan peningkatan teknologi yang digunakan perusahaan mebel kayu termasuk kategorisedang pembangunan ekonomi khusus pendapatan termasuk tingkat kategori tinggi, serta 2 dan 8 responden masing-masing menyatakan peningkatan teknologi yang digunakan perusahaan mebel kayu termasuk kategori tinggi tetapi pembangunan ekonomi khusus pendapatan termasuk kategori sedang dan rendah.

Tabel 15. Menunjukkan hasil analisis korelasi parsial dengan koefisien determinasi $\mathrm{r}^{2} \mathrm{y} 2.13=0,2282$ atau 22,82 persen dari variasi pembangunan ekonomi (Y) khusus pendapatan (Y1) dapat dijelaskan oleh faktor teknologi (X2) yang digunakan perusahaan mebel kayu (X), dalam penelitian ini teknologi yang diterapkan harus selektif dan tepat guna. Teknologi yang cocok dipedesaan adalah teknologi yang mudah disesuaikan dengan lingkungan yang relatif diperbaiki ditempat itu. Latihan lebih mudah dilakukan, tetapi teknologi itu harus produktif. Teknologi ini dikenal dengan sebutan teknologi madya, teknologi sederhana dan teknologi tepat guna.

Teknologi dalam penelitian ini adalah suatu perubahan dalam fungsi produksi digunakan perusahaan mebel kayu. Fungsi produksi yang dimaksud adalah penggunaan teknik produksi dalam meningkatkan hasil produksi. Dari data lapangan menunjukkan bahwa 6,66 persen responden masih berada pada kategori rendah, perusahaan belum mampu mengembangkan teknik perubahan model-model terbaru dari sebagian hasil produksi sebesar 5.277 unit per bulan pada kegiatan produksi dan tidak mampu melakukan teknik perubahan peralatan, karena peralatan yang digunakan masih sederhana (konvensional) untuk kegiatan produksi, 
Sedangkan 93,31 persen responden berada pada kategori sedangs ampai tinggi perusahaan dapat meningkatkan teknik mendesain dari hasil produksi sebesar 5.277 unit perbulanmelaluiketerampilankerja pada proses produksi dan mampu mengembangkan teknik perubahan model-model terbaru dari sebagian hasil produksi serta mampu melakukan teknik perubahan peralatan sederhana (konvensional) menjadi peralatan modern untuk meningkatkan mutu hasil produksi sebesar 5.277 unit per bulan pada kegiatan produksi.

Meningkatnya teknik penggunaan mesin disegala bidang kegiatan, maka semua kegiatan diperusahaan yang tadinya mampu diselesaikan dengan tangan, kini makin menurun jumlahnya. Dewasa ini pekerjaan banyak yang dapat dikerjakan dengan mesin. Keadaan ini mengurangi tenaga buruh.

Pada prinsipnya teknologi madya ini mendasarkan diri pada pandangan politik dan sosial, yaitu anjuran untuk masyarakat berpola hidup sederhana dan menghindari perkembangan perusahaan skala besar dipedesaan. Konsep teknologi yang cocok dengan alam dan lingkungan sosial merupakan salah satu inti yang paling pokok (Dharmawan, A.1986). Pemasukan teknologi tentunya tidak ditolak secara prinsip, sekalipun dalam praktek nyata benar akibatnya terhadap struktur sosial yang makin memincang. Memasyarakatkan teknologi pedesaan untuk mengolah potensi alam lingkungan dan memanfaatkan sumberdaya manusia masih merupakan beban dari potensi yang ada, guna menyediakan kesempatan kerja, meningkatkan pendapatan rakyat pedesaan (Rahardjo, D. 1986).

Pemilihan teknologi untuk menunjang proses perusahaan mebel kayu didesa Luwoo masih perlu diteliti lebih lanjut dampaknya terhadap pembangunan sosial dan ekonomi masyarakat. Yang pasti bahwa teknologi tersebut harus teknologi moderen atau padat modal yang dipilih akan mengakibatkan penyerapan tenaga kerja didasarkan pada pengembangan teknologi dari dalam dan bisa dilaksanakan. Jika yang makin lama makin menurun maka tidak akan tercipta kesempatan ekonomi bagi masyarakat yang ada dilingkungannya.

\section{Bahan Baku}

Bahan baku yang digunakan perusahaan mebel kayu merupakan kebutuhan pokok yang terdiri dari bahan baku langsung atau bahan kayu dan bahan baku tak langsung atau bahan penolong. Bahan baku yang digunakan produksi perusahaan mebel kayu berpengaruh pembangunan ekonomi (Y) khusus pendapatan (Y2). Tabel 15, menunjukkan hasil analisis kontingensi parsial dengan uji keberartian kontingensi parsial menyatakan bahwa faktor bahan baku (X3) yang digunakan perusahaan mebel kayu (X) mempunyai hubungan sangat signifikan terhadap pembangunan ekonomi (Y) khusus pendapatan (Y1). Model ini dibuktikan dengan nilai statistik $\chi^{2} 23_{\text {hit }}=10,23>$ $\chi_{\text {daf }}^{2}=9,49$ hipotesis $\mathrm{H} 1$ diterima pada taraf nyata $\alpha=0,05$ atau $5 \%$ memberikan pengujian yang sangat signifikan atau sangat berarti. Analisis kontingensi parsial ini, dapat dilihat pada tabel 18 sebagai berikut : 


\section{Tasharruf: Journal Economics and Business of Islam Vol. 4, No. 2 (2019):110-127 Website: http://journal.iain-manado.ac.id/index.php/TJEBI ISSN 2528-0325 (online) ISSN 2528-0317 (print)}

Tabel 18. Kontingensi Parsial

Antara (Y1) dan (X3)

\begin{tabular}{|c|c|c|c|c|c|c|c|}
\hline \multirow{2}{*}{$\begin{array}{c}\text { Analisis } \\
\text { Variabel X3 dan Y }\end{array}$} & \multicolumn{6}{|c|}{ Pendapatan (Y1) } & \multirow[t]{2}{*}{ Jumlah } \\
\hline & \multicolumn{2}{|c|}{ Tinggi } & \multicolumn{2}{|c|}{ Sedang } & \multicolumn{2}{|c|}{ Rendah } & \\
\hline \multicolumn{8}{|l|}{ Bahan Baku (X3) } \\
\hline Mudah & 2 & $6^{*}$ & 5 & $16^{*}$ & 0 & 0 & 22 \\
\hline Agak Sulit & 1 & $4 *$ & 0 & 0 & 0 & 0 & 4 \\
\hline Sulit & 1 & 4 & 0 & 0 & 0 & 0 & 4 \\
\hline Jumlah & & 14 & & 16 & & $\mathbf{0}$ & 30 \\
\hline
\end{tabular}

Tabel 18. Menunjukkan kontingensi parsial dari 30 responden yang diteliti, sebanyak 15 responden menyatakan kebutuhan bahan baku yang digunakan perusahaan mebel kayu termasuk kategori mudah dan pembangunan ekonomi khusus pendapatan termasuk kategori sedang, serta 6 dan 4 responden masing-masing menyatakan kebutuhan bahan baku yang digunakan perusahaan mebel kayutermasuk kategori mudah dan agak sulit dengan pendapatan termasuk tingkat kategori tinggi.

Tabel 16. Menunjukkan hasil analisis korelasi parsial dengan koefisien determinasi $\mathrm{r}^{2} \mathrm{y} 3.12=0,1922$ atau 19,22 persen dari variasi pembangunan ekonomi (Y) khusus pendapatan (Y1) dapat dijelaskan oleh faktor bahan baku (X3) yang digunakan perusahaan mebel kayu (X), dalam penelitian ini yang dimaksud dengan bahan baku adalah jumlah bahan baku kayu rata-rata sebesar $1.050 \mathrm{~kg}$ per bulan dan kualitas bahan baku kayu yang lebih baik memenuhi standar bentuk dan ukuran diameter $2 \mathrm{~cm}-50$ $\mathrm{cm}$ serta bahan penolong yang baik digunakan untuk proses produksi sesuai dengan kebutuhan setiap jenis produksi.

Salah satu keunggulan perusahaan kecil bahwa umumnya bahan baku dapat diperoleh pada pasar lokal. Bagi perusahaan mebel kayu didesa Luwoo, bahan baku masih dapat diperoleh didesa dan luar desa sehingga tidak mempengaruhi kegiatan perusahaan. Yang terpengaruh dalam hal ini adalah masyarakat setempat. Data lapangan (tabel lampiran 7) menunjukkan bahwa 73,34 persen responden menyatakan kategori mudah bahwa perusahaan mampu menggunakan jumlah bahan baku kayu rata-rata sebanyak $1.050 \mathrm{~kg}$ per bulan dan dapat menggunakan kualitas bahan baku kayu yang lebih baik memenuhi standar bentuk dan ukuran diameter $2 \mathrm{~cm}-50 \mathrm{~cm}$ serta dapat menggunakan bahan penolong yang baik untuk proses produksi sesuai dengan kebutuhan setiap jenis produksi.

Faktor manusia yang memberi kontribusi utama dalam pembangunan. Artinya bahwa, meskipun bahan baku sulit diperoleh didesa Luwoo dan diluar desa tetapi perusahaan tersebut bisa berjalan karena sumberdaya manusia yang ada sangat menunjang. 


\section{Tasharruf: Journal Economics and Business of Islam Vol. 4, No. 2 (2019):110-127 Website: http://journal.iain-manado.ac.id/index.php/TJEBI ISSN 2528-0325 (online) ISSN 2528-0317 (print)}

Hasil penelitian serta temuan-temuan yang diperoleh menarik untuk di telaah sebagai masukan dalam rangka pembinaan dan pengembangan perusahaan mebel kayu. Perlu dikaji agar keberadaan perusahaan itu, pelaku usaha, manfaat dan hasil yang adalah dari, oleh dan untuk penduduk desa Luwoo itu sendiri. Hal ini sangat penting penyusunan program pembangunan desa, karena industri pedesaan akan memberi peluang kerja serta meningkatkan pendapatan masyarakat pedesaan. Oleh karenanya esensi dan keberadaan industri pedesaan dalam rangka pembangunan nasional sangat diperlukan.Untuk menjelaskan masalah ini maka perlu dilihat latar belakang kehidupan masyarakat desa Luwoo sendiri serta konsep pembangunan yang sedang dan akan dilaksanakan.

Dari tingkat penyerapan tenaga kerja, ternyata kegiatan perusahaan mebel kayu ini mampu menyerap tenaga kerja sebanyak 203 jiwa atau 8,90 persen dari jumlah angkatan kerja yang ada didesa Luwoo yaitu kurang lebih berjumlah 664 jiwa atau 29,11 persen. Salah satu perusahaan yang menjadi objek penelitian adalah perusahaan mebel kayu. Dari tabel 12 diperoleh data lapangan menunjukkan bahwa 76,67 persen responden menyatakan kategori sedang sampai tinggi bahwa perusahaan dapat menyerap tenaga kerja yang produktif lebih dari 72 orang untuk kegiatan produksi sesuai dengan kebutuhan produksi dan dapat meningkatkan jumlah tenaga kerja yang produktif lebih dari 72 orang dalam rangka peningkatan hasil produksi sebesar 5.277 unit per bulan pada kegiatan produksi serta dapat meningkatkan kualitas tenaga kerja melalui latihan keterampilan kerja pada bidang produksi dalam rangka peningkatan mutu hasil produksi.

Sedangkan 23,33 persen responden berada pada kategori rendah bahwa perusahaan tidak dapat meningkatkan jumlah tenaga kerja yang produktif lebih dari 72 orang dalam rangka peningkatan hasil produksi sebesar 5.277 unit per bulan pada kegiatan produksi dan tidak dapat meningkatkan kualitas tenaga kerja melalui latihan ketrampilan kerja pada bidang produksi dalam rangka peningkatan mutu hasil produksi.

Nilai ekonomi barang ditentukan oleh tenaga kerja yang membuat barang itu, sehingga "human factor" akan memberi kontribusi yang besar dalam laju pertumbuhan pembangunan (Todaro, M.P. 1989). Keterampilan, pengetahuan dan pengalaman kerja penduduk desa Luwoo dalam membuat produk-produk perusahaan mebel kayu tidak perlu diragukan lagi sehingga dengan dukungan teori diatas diasumsikan bahwa perusahaan tersebut akan mampu meningkatkan pendapatan rumah tangga penduduk desa tersebut. Yang perlu dikaji sekarang adalah manajemen sumberdaya manusia serta sumberdaya-sumberdaya lainnya agar dapat diperoleh hasil yang maksimal.

Berdasarkan tingkat pendapatan pada tabel 13 diperoleh data lapangan menunjukkan bahwa 66,67 persen responden menyatakan berada sampai tingkat pendapatan yang sedang sampai tinggi yaitu perusahaan dapat memberikan pendapatan yang diperoleh karyawan sebesar Rp. 10.000,- sampai dengan Rp. 30.000,- per hari sesuai dari pekerjaannya yang produktif dan mampu menaikkan pendapatan bagi karyawan yang lebih tinggi dari Rp. 10.000,- sampai dengan Rp. 30.000,- per hari sesuai dengan peningkatan jumlah volume produksi setiap unit per hari serta dapat memberikan pendapatan yang diperoleh karyawan sebesar Rp. 10.000,- sampai dengan

122 | Peranan Perusahaan Mebel Kayu terhadap Pembangunan Ekonomi Kabupaten Gorontalo Usman Musa Sjahrain 
Rp. 30.000,- per hari memenuhi kebutuhan hidup bagi dirinya sendiri dan keluarga. Sedangkan 33,34 persen responden menyatakan berada pada tingkat pendapatan yang rendah yaitu industri dapat memberikan pendapatan yang diperoleh karyawan sebesar Rp. 10.000,- sampai dengan 30.000,- per hari tidak sesuai dari hasil pekerjaaanya yang produktif dalam kegiatan produksi dan tidak mampu menaikkan pendapatan bagi karyawan sebesar Rp. 10.000,- sampai denganRp. 30.000,- per hari karena jumlah volume produksi setiap unit perhari mengalami penurunan serta pendapatan yang diperoleh karyawan sebesar Rp. 10.000,- sampai dengan 30.000,- per hari belum memenuhi kebutuhan hidupnya sendiri dan keluarga. Dari gambaran ini nampak bahwa kegiatan perusahaan mebel kayu ini sesungguhnya belum dapat dijadikan tulang punggung perekonomian desa Luwoo karena perusahaan dapat memberikan pendapatan yang diperoleh karyawan belum dapat memenuhi kebutuhan hidup bagi karyawan itu sendiri, keluarga dan masyarakat.

Perusahaan sebagai upaya untuk meningkatkan taraf hidup manusia memerlukan pengelola yang tepat. Berdasarkan penelitian yang dilakukan terlihat bahwa gejala ini suatu hal yang utama dan memberikan kepastian bahwa perusahaan mebel kayu dapat berkembang jika dikelola secara profesional. Dalam kasus perusahaan mebel kayu di desa Luwoo ini hal tersebut merupakan kegiatan yang cukup potensial karena tumbuh dan berkembang dari masyarakat (indigeneous), bukan merupakan perusahaan yang diimport dari luar. Indikasi perkembangannya terlihat dari kemampuan menyerap tenaga kerja sebanyak 203 jiwa atau 8,90 persen dari jumlah angkatan kerja yang ada didesa Luwoo.

Berdasarkan pada temuan-temuan dan hasil penelitian diatas maka dapat diasumsikan bahwa pada saat nanti perusahaan mebel kayu dapat menjadi tulang punggung masyarakat desa Luwoo disamping sektor-sektor lain. Hal ini dapat berjalan dengan persyaratan bahwa sistem manajemen dan kelembagaan di desa telah tertata dengan baik, serta masyarakat disitu menjadi obyek dan subyek kegiatan tersebut sehingga pada saatnya nanti tingkat penyerapan tenaga kerja akan makin besar, kesempatan ekonomi akan tumbuh dan tingkat pendapatan keluarga akan beranjak naik, sehingga pemenuhan kebutuhan fisik keluarga dan masyarakat desa akan terpenuhi dan meningkat.

\section{KESIMPULAN DAN SARAN}

\section{Kesimpulan}

Berdasarkan hasil penelitian diperoleh kesimpulan sebagai berikut:

1. Perusahaan mebel kayu yang menggunakan modal, teknologi dan bahan baku secara bersama-sama (simultan) berperan dalam pembangunan ekonomi khusus pendapatan masyarakat Desa Luwoo Kecamatan Telaga Jaya Kabupaten Gorontalo. Sebab 76,67 persen pengusaha atau karyawan berada pada kategori sedang dan tinggi, Perusahaan mebel kayu dapat menyerap tenaga kerja yang produktif sesuai dengan kebutuhan produksi dan hanya 66,67 persen pengusaha atau karyawan berada pada 
Tasharruf: Journal Economics and Business of Islam Vol. 4, No. 2 (2019):110-127 Website: http://journal.iain-manado.ac.id/index.php/TJEBI ISSN 2528-0325 (online) ISSN 2528-0317 (print)

kategori sedang dan tinggi, Perusahaan mebel kayu belum memberikan pendapatan yang lebih tinggi sesuai dengan pekerjaannya.

2. Modal, teknologi dan bahan baku yang digunakan Perusahaan mebel kayu secara bersama-sama (simultan) merupakan suatu kesatuan yang dapat digunakan sebagai penduga yang mempunyai hubungan sangat signifikan terhadap pembangunan ekonomi khuusus pendapatan masyarakat Desa Luwoo Kecamatan Telaga Jaya Kabupaten Gorontalo. Karena hanya 51,94 persendarivariasi pembangunan ekonomi khusus pendapatandapat dijelaskan oleh faktor - faktor modal, teknologi dan bahan baku secara bersama-sama (simultan) yang digunakan perusahaan mebel kayu.

3. Modal yang digunakan perusahaan mebel kayu berperan terhadap pembangunan ekonomi khuususpendapatan. Faktor modal yang digunakan perusahaan mebelkayu mempunyai hubungan sangat signifikan terhadap pembangunan ekonomi khuusus pendapatan. sebab 63,33 persen pengusaha atau karyawan berada pada kategori agak sulit dan sulit, perusahaan mebel kayu memiliki modal berupa peralatan yang lengkap dan dana yang cukup dikeluarkan dari usaha sendiri karena didesa Luwoo belum tersedia lembaga keuangan yang dapat menyandang dana bagi kegiatan produksi.

4. Teknologiyangdigunakan perusahaan mebel kayu berperan terhadap pembangunan ekonomi khusus pendapatan. Faktor teknologi yang digunakan perusahaan mebel kayu mempunyai hubungan tidak signifikan terhadap pembangunan ekonomi khuusus pendapatan, karena 93,31 persen pengusaha atau karyawan berada pada kategori sedang dan tinggi, perusahaan mebel kayu dapat menggunakan teknik produksi dalam meningkatkan volume dan mutu hasil produksi.

5. Bahan baku yang digunakan perusahaan mebel kayu berperan pembangunan ekonomi khuususpendapatan.Faktor bahan baku yang digunakan perusahaan mebel kayu mempunyai hubungan sangat signifikan terhadap pembangunan ekonomi khuususpendapatan, karena 73,34 persen pengusaha atau karyawan berada pada kategori mudah, perusahaan mebel kayu dapat menggunakan jumlah dan kualitas bahan baku rotan dan bahan penolong yang lebih baik memenuhi standar dan ukuran sesuai dengan kebutuhan setiap jenis produksi.

\section{Saran}

Saran-saran yang dapat dilakukan adalah sebagai berikut:

1. Perlunya diupayakan berdirinya lembaga-lembaga keuangan seperti Koperasi Unit Desa (KUD) atau Bank Desa yang dapat menyandang dana dan membantu pemasaran perusahaan mebel kayu. Hal ini diperlukan agar pengusaha dan karyawan dapat berakses langsung dengan mereka, demikian halnya dengan penunjukan bapak angkat, kiranya mereka yang ditunjuk yaitu yang mempunyai alur produksi yang terkait, sehingga ada ketergantungan yang saling menguntungkan.

2. Teknologi yang diterapkan pada perusahaan mebel kayu dipedesaan sebaiknya yang tepat guna dan harus selektif agar mampu menciptakan kesempatan kerja dan meningkatkan pendapatan masyarakat desa. Perlu dihindari penggunaan teknologi 
Tasharruf: Journal Economics and Business of Islam Vol. 4, No. 2 (2019):110-127 Website: http://journal.iain-manado.ac.id/index.php/TJEBI ISSN 2528-0325 (online) ISSN 2528-0317 (print)

yang menyebabkan penurunan tingkat penyerapan tenaga kerja dan melumpuhkanpertumbuhanekonomi.Hal ini mengakibatkan terjadinya pengangguran dimasyarakat makin banyak.

3. Kiranya pemerintah bersama-sama dengan masyarakat setempat menggalakan penghijauan kembali hutan-hutan diwilayah sekitar desa Luwoo dengan tanaman kayu yang bernilai ekonomi sehingga menjadi hutan tanaman perusahaan. Hal ini akan menjamin kelanjutan penyediaan bahan baku yang terdapat didesa Luwoo, dan mensukseskan program pembangunan yang berkelanjutan.

4. Perlu dilakukan penelitian lanjutan untuk mengungkapkan beberapa variabel pada kegiatan perusahaan mebel kayu diduga berperan dalam pembangunan ekonomi khususnya pendapatan masyarakat desa Luwoo Kecamatan Telaga Jaya Kabupaten Gorontalo, namun belum terungkap dalam penelitian ini.

\section{DAFTAR PUSTAKA}

Abdullah. 1992. Materi Pokok Pendidikan IPS-2 Jakarta: Buku 1, Modul 1.

Ali Chidir, 1987, Badan Hukum, Jakarta: Alumni.

Amir, M.S. 1996.Letter of Credit Dalam Bisnis Ekspor Impor. Jakarta: Lembaga Manajemen PPM dan Penerbit PPM.

Arikunto, S. 1993, Prosedur Penelitian Suatu Pendekatan Praktek, Jakarta : Rineka Cipta

Arsyad, Lincolin. 2010. Ekonomi Pembangunan Jakarta: Bagian Penerbitan STIE,

Clapman, R.1991, Pengusaha Kecil dan Menengah di Asia Tenggara, Jakarta : LP3ES,

Dharmawan, A.1986, Aspek-Aspek Dalam Sosiologi Industri, Bandung : Bina Cipta

Hartono, Sri Rejeki, 14-18 Juli 2003. Pembangunan Hukum Nasional. Denpasar, Makalah Seminar dan Lokakarya VIII.

Indriani, Darma 2011.Pengaruh pengeluaran konsumsi dan investasi pemerintah terhadap pertumbuhan ekonomi di Indonesia.

Irawan, 1999, Ekonomika Pembangunan, Yogyakarta : BPFE,

Kitab Undang-Undang Hukum Dagang (KUHD) atau Wetboek van Koophandel Indonesia $(\mathrm{WvK})$

Kramer, S.L. 1996, Geotechnical Earthquake Engineering,: Prentice Hall, Englewood Cliffs, N. J, h. 653. 
Tasharruf: Journal Economics and Business of Islam Vol. 4, No. 2 (2019):110-127 Website: http://journal.iain-manado.ac.id/index.php/TJEBI ISSN 2528-0325 (online) ISSN 2528-0317 (print)

Leibo, J. 1995, Sosiologi Pedesaan, Yogyakarta: Andi Offset

Malingkas, H.J. 1995, Pengaruh Industri Rumah Kayu Model Minahasa Terhadap Pembangunan Masyarakat Woloan Kecamatan Tomohon Propinsi Sulawesi Utara, Tesis Program Pascasarjana Unsrat, Manado.

Mashudi, Djohan. Taufiq, M dan Priana W. 2017, Pengantar Teori Ekonomi, Yogyakarta: Gosyen Publishing, Cet.1. h. 3.

Muhammad Abdulkadir, 2002, Hukum Perusahaan Indonesia, Bandung: Citra Aditya Bakti, Hlm. 7.

Muhammad, Abdulkadir. 2003. Hukum Perusahaan Indonesia. Bandung: PT. Citra Aditya Bakti. Terkait

Mullineux, Andy. 2000. “Investasi” dalam Kuper, Adam \& Kuper, Jesica, (ed)

Nawawi, H. dan M. M. Hadari, 1995, Instrumen Penelitian Bidang Sosial, Yogyakarta : Gadjah Mada University Press

Rahardjo, D. 1986, Transformasi Pertanian, Industri dan Kesempatan Kerja,Jakarta : Universitas Indonesia Press.

Sadono Sukirno. 2006. Pembangunan ekonomi dan Pertumbuhan ekonomi

Sandy, I.M. 1985, Republik Indonesia Geografi Regional, Jakarta : Puri Margasari,

Salvatore, D \& Dowling, E. T. 2006. Theory And Problems at Economic development, Mc-Graw Hill, New York.

Siagian, S.P. 1988, Proses Pengelolaan Pembangunan Nasional, Jakarta : PT. Tema Baru

Sudarto, 1997, Metodologi Penelitian filsafat, Jakarta: Raja Grafindo Persada,cet. ke2

Sudjana, 1992, Metoda Statistika, Bandung: Tarsito, Cet. 5. h. 2.

Sugiarto, 2001, Teknik Sampling, Jakarta : PT. Gramedia Pustaka Utama

Sugiyono, 1999, Statistik Nonparametris untuk penelitian, Bandung:CV. Alfabeta

Suharto, 1992, Manajemen dan Rekayasa Sistem Produksi, Jakarta:Pradnya Paramita

Sukirno, Sadono. 1994, Mikro Ekonomi Teori Pengantar, Jakarta : PT. RajaGrafindo Persada

1996. Pengantar Teori Makro Ekonomi, Jakarta: PT Raja Grafindo Persada, 
Tasharruf: Journal Economics and Business of Islam Vol. 4, No. 2 (2019):110-127 Website: http://journal.iain-manado.ac.id/index.php/TJEBI ISSN 2528-0325 (online) ISSN 2528-0317 (print)

Supangat Andi, 2010, Statistika Dalam Kajian Deskriptif, Inferensi, dan Nonparametrik, Jakarta: Kencana, Cet. 3. h.1.

Suparlan, P. 1984, Kemiskinan di Perkotaan, Jakarta : Yayasan Obor Indonesia,

Suria sumantri, Jujun, 2001, Ilmu Dalam Perspektif, Jakarta: Yayasan Obor Indonesia, cet. ke2, h. 201.

Suryana, 2000.Ekonomi Pembangunan (Problematika dan Pendekatan)”, Bandung: Salemba Empat.

Soehartono, I. 1998, Metode Penelitian Sosial, Bandung : PT. Remaja Rosdakarya.

Soeparmo,R. 1987, Mengenal Desa, Gerak dan Pengelolaannya, Jakarta: PT. Intermasa.

Soeroto, 1986, Strategi Pembangunan dan Perencanaan Tenaga Kerja, Yogyakarta : Gadjah Mada University Press

Tjiptohadiriyanto, P. 1982, Sumberdaya Manusia, Kesempatan Kerja dan Pembangunan Ekonomi,Jakarta : FEUI.

Todaro, M.P. 1989, Pembangunan Ekonomi, Jakarta : Erlangga

Usman Rachmadi, 2000, Hukum Ekonomi dalam Dinamika. Jakarta. Djambatan.

Undang - Undang Dasar 1945, Pembukaan, alinea ke empat.

Undang - Undang Nomor 3 Tahun 1982 Tentang Wajib Daftar Perusahaan

Undang - Undang Nomor 8 Tahun 1997 Tentang Dokumen Perusahaan

Walpole, R E. dan R.H. Myers, 1986, Ilmu Peluang dan Statistika Untuk Insinyur dan Ilmuwan, Bandung : ITB

Walpole, R.E. 1997, Pengantar Statistika, Jakarta: PT.Gramedia Pustaka Utama

Widjaya, Rai, 2002, Hukum Perusahaan, Bekasi: Megapoin: Kesaint BlancIKAPI.

Thirwall, A.P. 2005.Finance Economic Development, London: McMillan Press Ltd. 